\title{
Mineralogy and Fluid Regime of Formation of the REE-Late-Stage Hydrothermal Mineralization of Petyayan-Vara Carbonatites (Vuoriyarvi, Kola Region, NW Russia)
}

\author{
Ilya Prokopyev ${ }^{1,2, *}$, Evgeniy Kozlov ${ }^{3}\left(\mathbb{D}\right.$, Ekaterina Fomina ${ }^{3}\left(\mathbb{D}\right.$, Anna Doroshkevich ${ }^{1,4}$ and \\ Maxim Dyomkin ${ }^{1,2}$ \\ 1 Sobolev Institute of Geology and Mineralogy, Siberian Branch of the Russian Academy of Sciences, \\ Akademika Koptyuga Avenue 3, 630090 Novosibirsk, Russia; doroshkevich@igm.nsc.ru (A.D.); \\ m.demkin@g.nsu.ru (M.D.) \\ 2 Department of Geology and Geophysics, Novosibirsk State University, Pirogova Street 1, \\ 630090 Novosibirsk, Russia \\ 3 Geological Institute, Kola Science Centre, Russian Academy of Sciences, Fersmana Street 14, 184209 Apatity, \\ Russia; kozlov_e.n@mail.ru (E.K.); fomina_e.n@mail.ru (E.F.) \\ 4 Geological Institute, Siberian Branch of the Russian Academy of Sciences, Sakhyanova Street 6a, \\ 670047 Ulan-Ude, Russia \\ * Correspondence: prokop@igm.nsc.ru; Tel.: +7-913-387-8321
}

Received: 10 April 2020; Accepted: 29 April 2020; Published: 29 April 2020

Abstract: The Vuoriyarvi Devonian alkaline-ultramafic complex (northwest Russia) contains magnesiocarbonatites with rare earth mineralization localized in the Petyayan-Vara area. High concentrations of rare earth elements are found in two types of these rocks: (a) ancylite-dominant magnesiocarbonatites with ancylite-baryte-strontianite-calcite-quartz ( \pm late $\mathrm{Ca}-\mathrm{Fe}-\mathrm{Mg}$ carbonates) ore assemblage, i.e., "ancylite ores"; (b) breccias of magnesiocarbonatites with a quartz-bastnäsite matrix ( \pm late $\mathrm{Ca}-\mathrm{Fe}-\mathrm{Mg}$ carbonates), i.e., "bastnäsite ores." We studied fluid inclusions in quartz and late-stage $\mathrm{Ca}-\mathrm{Fe}-\mathrm{Mg}$ carbonates from these ore assemblages. Fluid inclusion data show that ore-related mineralization was formed in several stages. We propose the following TX evolution scheme for ore-related processes: (1) the formation of ancylite ores began under the influence of highly concentrated (>50 wt.\%) sulphate fluids (with thenardite and anhydrite predominant in the daughter phases of inclusions) at a temperature above $300-350^{\circ} \mathrm{C}$; (2) the completion of the formation of ancylite ores and their auto-metasomatic alteration occurred under the influence of concentrated (40-45 wt.\%) carbonate fluids (shortite and synchysite-Ce in fluid inclusions) at a temperature above $250-275{ }^{\circ} \mathrm{C}$; (3) bastnäsite ores deposited from low-concentrated (20-30 wt.\%) hydrocarbonate-chloride fluids (halite, nahcolite, and/or gaylussite in fluid inclusions) at a temperature of $190-250{ }^{\circ} \mathrm{C}$ or higher. Later hydrothermal mineralization was related to the low-concentration hydrocarbonate-chloride fluids ( $<15 \mathrm{wt} . \% \mathrm{NaCl}$-equ.) at $150-200^{\circ} \mathrm{C}$. The presented data show the specific features of the mineral and fluid evolution of ore-related late-stage hydrothermal rare earth element (REE) mineralization of the Vuoriyarvi alkaline-ultramafic complex.

Keywords: magnesiocarbonatites; REE; ancylite; bastnäsite; fluid inclusion; Vuoriyarvi; Kola Alkaline Province

\section{Introduction}

Carbonatites are igneous rocks, which are composed of more than 50 vol.\% of primary magmatic carbonates and less than $20 \mathrm{wt} . \%$ of $\mathrm{SiO}_{2}$ [1]. Today, carbonatites and their weathering crusts are the 
main sources of niobium and rare earth elements (REEs) in the world. Approximately 51.4\% of global rare earth oxide resources are hosted by carbonatite deposits, and bastnäsite, monazite, and xenotime are the three most significant REE minerals, accounting for $>90 \%$ of the total resources [2]. REEs are considered critical metals because of their extensive use in modern and "green" technologies $[3,4]$. Therefore, the study of REE-carbonatite complexes, namely, mineralogy and ore formation processes, is relevant today and plays an important role in fundamental science and in exploring the production process. Importantly, the weight percentage levels of REEs that are required for an economic deposit commonly occur in magnesio- and iron-rich carbonatite dykes and veins [4,5]. Therefore, magnesioand iron-rich carbonatites are a major focus of critical metal research.

The Kola region in NW Russia is host to some of the largest REE reserves. The measured and indicated $\mathrm{REE}_{2} \mathrm{O}_{3}$ resources of all deposits in the region are 22.4 and 36.2 million tonnes, respectively [6]. This puts the Kola region on par with the largest sources of REEs in the world [2,4]. The REE potential of the Kola region is mainly associated with the intrusive complexes of the Devonian Kola Alkaline Province and primarily with the giant agpaitic nepheline-syenite complexes of Khibina (resources 11.5 Mt $\mathrm{REE}_{2} \mathrm{O}_{3}$, average ore content $0.36 \mathrm{wt}$ \% $\mathrm{REE}_{2} \mathrm{O}_{3}$ ) and Lovozero (resources $7.3 \mathrm{Mt} \mathrm{REE}_{2} \mathrm{O}_{3}$, average ore content $0.78 \mathrm{wt} . \% \mathrm{REE}_{2} \mathrm{O}_{3}$ ) (see [6] and the references therein). Therefore, a specific feature of the Kola region is that the bulk of REE resources are hosted by silicate rocks.

However, in addition to Khibina and Lovozero, other intrusive complexes of the Kola Alkaline Province also provide important contributions, most of which are alkaline-ultramafic carbonatite complexes [7-15]. For instance, the indicated rare earth resources of baryte-siderite and baryte-ankerite carbonatites of the Sallanlatvi complex are $1.0 \mathrm{Mt} \mathrm{REE}_{2} \mathrm{O}_{3}$ and average ore content is $0.42 \mathrm{wt} . \%$ $\mathrm{REE}_{2} \mathrm{O}_{3}$ [15]. However, the resources of most alkaline-ultramafic complexes in the Province have not been estimated because of a lack of knowledge about REE-bearing rocks. One of these complexes is Vuoriyarvi, in which the presence of REE-carbonatites from the Petyayan-Vara field has been established $[15,16]$. To date, the REE resources in these carbonatites have not been calculated; however, they are potentially the most promising carbonatite-related REE deposits in the Kola region. As shown in Kozlov et al. [16], the rare earth mineralization of Petyayan-Vara carbonatites is represented by two types of ores:

1. Ancylite-dominant magnesiocarbonatites with ancylite-baryte-strontianite-calcite-quartz $( \pm$ late $\mathrm{Ca}-\mathrm{Fe}-\mathrm{Mg}$ carbonates) ore assemblage.

2. Breccias of magnesiocarbonatites with a quartz-bastnäsite matrix ( \pm late $\mathrm{Ca}-\mathrm{Fe}-\mathrm{Mg}$ carbonates).

Supposedly, the second type of ore developed due to the first, as a result of its dissolution, remobilization, and deposition into REE-bastnäsite, as well as Sr removal with the formation of strontianite at a distance [16]. The conditions in which these processes take place have stimulated a good deal of interest. To obtain this information, the technique of studying fluid inclusions in minerals has been successfully applied to many REE-carbonatites and associated alkaline rocks across the world (e.g., [17-29]). Numerous ore-bearing carbonatite complexes and large deposits have experienced a multi-stage magmatic-hydrothermal evolution; and their REE enrichment has been mostly related to the late stages of hydrothermal-metasomatic processes, which are controlled by orthomagmatic ore-forming carbonatitic fluids, e.g., the Mianning-Dechang REE-carbonatite belt, SW China [18-21,23,25], magnetite-apatite and F-REE rocks of the Mushgai-Khudag alkaline-carbonatite complex in South Mongolia [24], REE-apatite dolomitic ores of the Seligdar magnesiocarbonatites (Central Aldan, Russia) [26,29], REE mineralization of the Songwe Hill carbonatites in Malawi [28] and many others.

In the case of Petyayan-Vara carbonatites, quartz and late $\mathrm{Ca}-\mathrm{Fe}-\mathrm{Mg}$ carbonates are minerals that are characteristic of REE-late-stage hydrothermal mineralization. Our study on inclusions in these minerals made it possible to establish a fluid regime for the formation of REE hydrothermal mineralization of the later stage of Petyayan-Vara magnesiocarbonatites. In doing so, we focused on the PTX-parameters responsible for the concentration and distribution of barium-strontium and rare earth mineralization in the evolution of mineral assemblages. 


\section{Geological Setting}

The Vuoriyarvi alkaline-ultramafic carbonatite complex is located within the Kola Alkaline Province. This Province includes more than 20 complexes comprising various ultramafic and alkaline rocks-olivinites, clinopyroxenites, diverse melilititic (turjaites, uncompahgrites, okaites) and diopside-nepheline rocks (melteigites, ijolites, urtites), as well as nepheline syenites, that range in age from ca. 385 to $360 \mathrm{Ma}$ [7-15]. Like all other alkaline-ultramafic intrusions in the Province, Vuoriyarvi was found to have a multiphase structure, which reflects the successive intrusion of an alkaline ultramafics-foidolite-carbonatite series $[7,10,12,15]$. Geochemically contrasting magmas are produced in the sequence of formation olivinites, pyroxenites, foidolites, nepheline syenites and carbonatites (Figure 1).

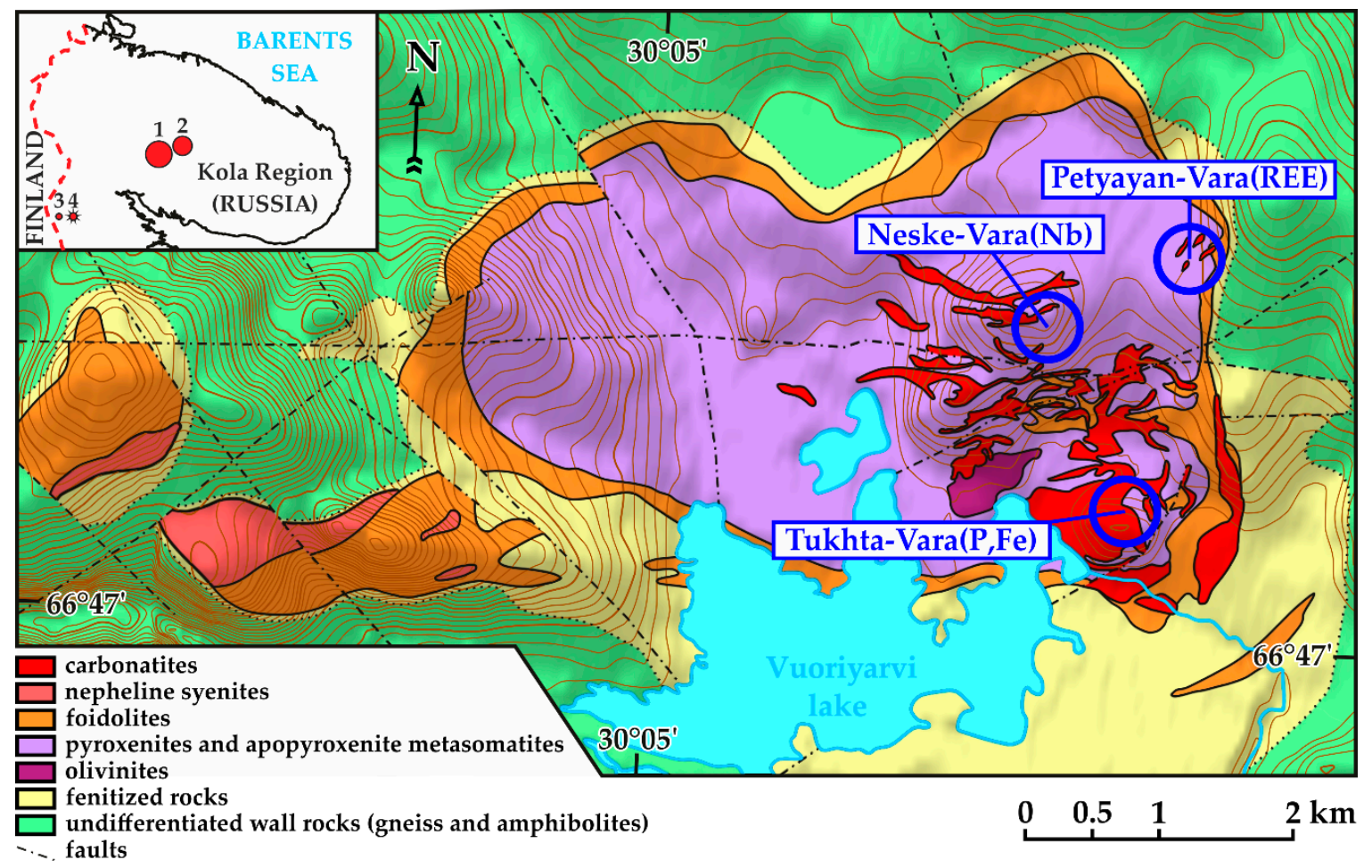

Figure 1. The geological setting and structure of the Vuoriyarvi alkaline-ultramafic carbonatite complex [16]. Blue circles indicate the positions of the Tukhta-Vara, Neske-Vara, and Petyayan-Vara carbonatite fields. The insert shows the position of the REE-rich complexes of the Kola Alkaline Province mentioned in the text: 1-Khibina, 2-Lovozero, 3-Sallanlatvi, and 4-Vuoriyarvi.

The Vuoriyarvi complex comprises several carbonatite fields: Neske-Vara, Tukhta-Vara, and the investigated Petyayan-Vara. Carbonatites of the Tukhta-Vara and Neske-Vara fields are localized in the central and southeastern part of the complex. They are predominantly represented by calciocarbonatites with ore minerals such as apatite $(\mathrm{P})$, magnetite $(\mathrm{Fe})$, and pyrochlore $(\mathrm{Nb})$. The Petyayan-Vara carbonatites are located in the northeastern part of the Vuoriyarvi alkaline complex and form several intruded linear bodies of a specific type of magnesiocarbonatite. The Petyayan-Vara field is represented by magnesiocarbonatites with $\mathrm{Ti}-\mathrm{Nb}, \mathrm{Ba}-\mathrm{Sr}$, and REE mineralization. In this field, the carbonatites are spatially associated with melteigites, ijolites, and pyroxenites. A considerable amount of the alkaline rock was metasomatically altered, forming coarse- and gigantic-grained phlogopite glimmerites, particularly in the areas adjacent to carbonatite veins. The magnesiocarbonatites form veins and lenses of several hundred meters in length and up to tens of meters in width.

The present data $[16,30]$ show that the Petyayan-Vara carbonatites are divided into several groups that differ in mineral composition (described below in the order of formation): 
1. Magnesiocarbonatites, consisting of dolomite and ancylite-strontianite-baryte pseudomorphs after burbankite. These carbonatites are primarily magmatic. They were altered to varying degrees during several metasomatic events.

2. High-Ti carbonatites composed of dolomite, microcline, Ti oxides ( \pm phlogopite, pyrochlore, and pyrite). Locally high-Ti carbonatites are enriched in apatite (+zircon; \pm aegirine and albite). These rocks were formed as a result of the introduction of a carbonatitic fluid (or fluid-saturated melt) rich in $\mathrm{K}, \mathrm{Al}, \mathrm{Si}, \mathrm{Fe}$, and $\mathrm{Ti}$ at the final stage of magmatic activity.

3. Baryte-dominant (dolomite + baryte) and ancylite-dominant (ancylite-baryte-strontianite-calcite-quartz \pm late $\mathrm{Ca}-\mathrm{Fe}-\mathrm{Mg}$ carbonates; "ancylite ores") magnesiocarbonatites. Alteration of primary magnesiocarbonatites is caused by a magmatic S-rich fluid with high concentrations of $\mathrm{Ba}$, Sr, and REE.

4. Late giant-grained carbothermal calciocarbonatites localized near the ancylite-dominant rocks.

5. Breccias of magnesiocarbonatites with a quartz-bastnäsite matrix ("bastnäsite ores"). These are the product of the final stage of the formation of Petyayan-Vara carbonatites during which the ancylite was dissolved, and REEs were deposited in bastnäsite (predominantly hydroxylated) in cracks and crush zones. Strontianite-dominant rocks, in which $\mathrm{Sr}$ was released from ancylite, are complementary to bastnäsite ores. Also, monazite, thorite, iron oxides and hydroxides, late $\mathrm{Ca}-\mathrm{Fe}-\mathrm{Mg}$ carbonates and calcite were crystallized at the late stage of carbonatite formation.

"Hybrid" rocks are also widespread. They were formed in the course of several processes and are represented by mineral assemblages of different mineral groups. The proposed paragenetic sequence of minerals in Petyayan-Vara carbonatites is shown in Figure 2. In the largest carbonatite bodies, all listed rock species and the corresponding paragenetic associations coexist in complex geological relationships. Small veins (several tens of $\mathrm{cm}$ in width) are usually composed of one or two rock species.

Quartz and late carbonates (such as calcite, several generations of dolomite, kutnohorite, and ankerite) appear in the mineral assemblages of the main REE ore stage ("ancylite ores") and are traced into all later mineral assemblages, including those formed at the final stage of the mineral formation of carbonatites [16]. Thus, quartz and late $\mathrm{Ca}-\mathrm{Mg}-\mathrm{Fe}$ carbonatites can serve as a monitor of the process of REE accumulation and subsequent redistribution at the final stage of the formation of Petyayan-Vara magnesiocarbonatites. 


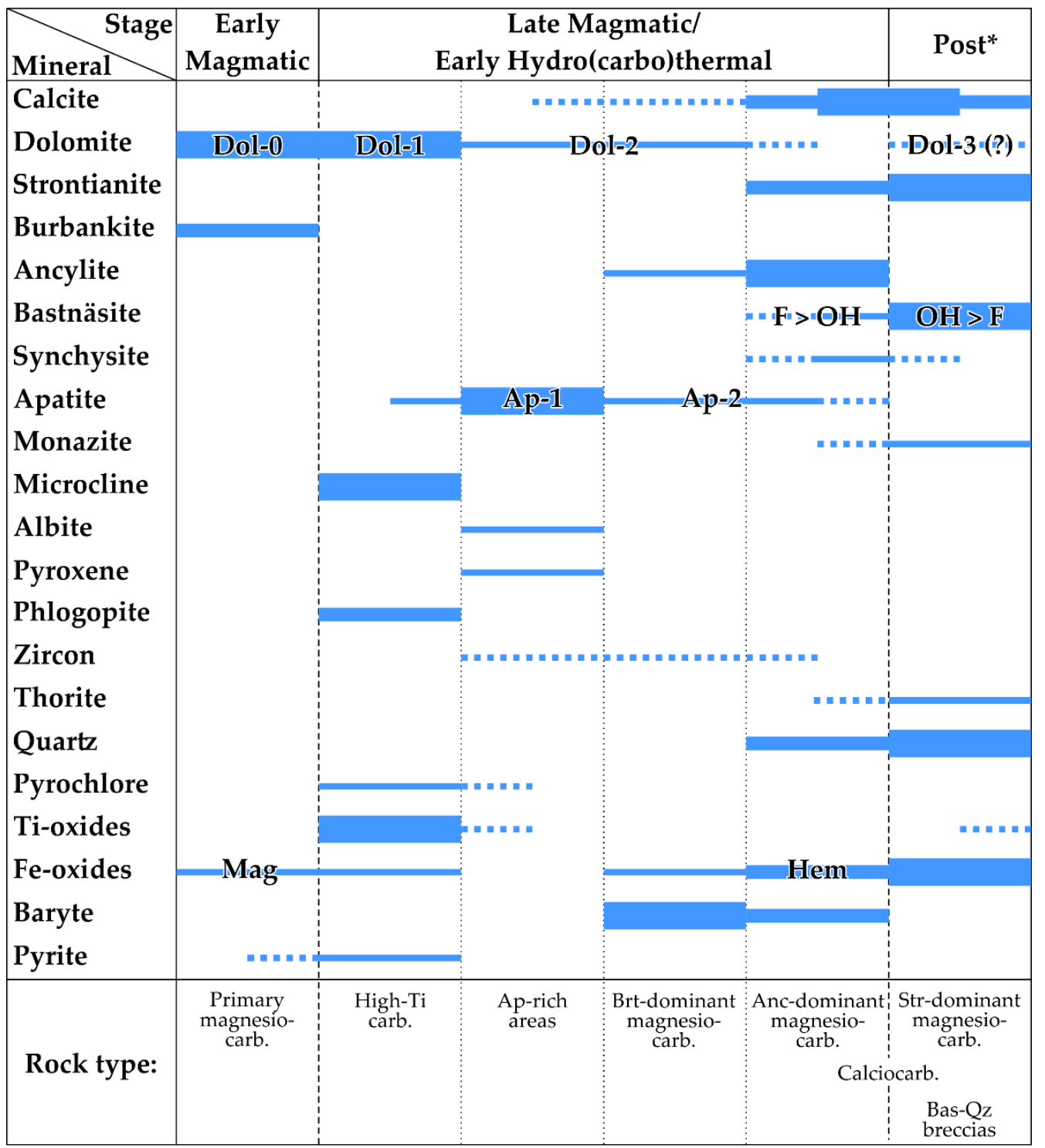

Mineral precipitation

Possible mineral precipitation

Figure 2. The proposed paragenetic sequence of minerals in Petyayan-Vara carbonatites [16]. Note: Post* includes both the late hydro(carbo)thermal and the supergene stages. Line thickness indicates deposition intensity.

\section{Sampling Procedure and Analytical Methods}

Representative samples from three types of quartz-containing rocks were used for the mineralogical and fluid inclusion investigations: (1) ancylite-dominant magnesiocarbonatites ("ancylite ores"), (2) breccias of magnesiocarbonatites with a quartz-bastnäsite matrix ("bastnäsite ores"), and (3) "hybrid" rocks bearing all of the established mineral assemblages of Petyayan-Vara magnesiocarbonatites.

Polished thin sections were prepared for petrographic investigation and polished rock samples were prepared for ore mineralogy and studied in transmitted and reflected light, respectively, under a polarizing microscope Olympus BX51 with a photo camera device. The polished rock samples were used to determine the rock textures and the mineral assemblages using energy-dispersive spectrometry in combination with back-scattered electron imaging (BSE) of the TESCAN MIRA 3 LMU JSM-6510LV scanning electron microscope with energy-prefix X-Max Oxford Instruments.

The mineral compositions were determined using the electron microprobe JEOL JXA-8100 (WDS mode, $20 \mathrm{kV}, 15 \mathrm{nA}, 1-2 \mu \mathrm{m}$ beam diameter). The accumulation time for analyzing F (using LDE 
crystal) was $40 \mathrm{~s}$ (20 s of counting the background; $20 \mathrm{~s}$ of counting a peak for F), and the detection limit for $\mathrm{F}$ was $477 \mathrm{ppm}(0.04 \mathrm{wt}$ \%). For carbonate minerals analysis, we used a beam current of $10 \mathrm{nA}$ and an acceleration voltage of $15 \mathrm{kV}$; for Fe-Ti oxides, $20 \mathrm{nA}$ and $15 \mathrm{kV}$; for monazite, $40 \mathrm{nA}$ and $20 \mathrm{kV}$; and for apatite, $10 \mathrm{nA}$ and $20 \mathrm{kV}$. The peak counting time was $16 \mathrm{~s}$ for major elements and 30-60 s for minor elements. For calibration, both natural minerals and synthetic phases were used as standards (element detection limits in ppm): $\mathrm{SiO}_{2}(\mathrm{Si}, 158)$, rutile $(\mathrm{Ti}, 120), \mathrm{LiNbO}_{3}(\mathrm{Nb}, 142)$, Sr silicate glass ( $\mathrm{Sr}$, $442)$, albite $(\mathrm{Na}, 176)$, orthoclase $(\mathrm{K}, 182), \mathrm{Al}_{2} \mathrm{O}_{3}(\mathrm{Al}, 128)$, F-apatite (Ca, 115; P, 387; F, 477), Mn-garnet (Mn, 129), hematite (Fe, 148), $\mathrm{CePO}_{4}(\mathrm{Ce}, 236), \mathrm{LaPO}_{4}(\mathrm{La}, 272), \mathrm{BaSO}_{4}(\mathrm{~S}, 178), \mathrm{NdPO}_{4}(\mathrm{Nd}, 362)$, $\mathrm{Cl}$-apatite $(\mathrm{Cl}, 74)$, and $\mathrm{PrPO}_{4}(\mathrm{Pr}, 401)$. Mineral analyses were processed by an in-house computer program with ZAF correction.

Double-polished thin sections were prepared for fluid inclusion investigations. Raman spectroscopy was applied to determine the composition of the gas and crystalline solid phases of the fluid inclusions. Raman spectra were obtained on a LabRam HR800 Horiba Jobin Yvon spectrometer, equipped with an optical microscope (Olympus BX41). The $514.5 \mathrm{~nm}$ Ar + laser line was used for spectra excitation. The well-known RRUFF (http://rruff.info) database of Raman spectra was used for the identification of solid phases. Heating and freezing experiments were carried out using a Linkam THMSG-600 stage with a measuring range from -196 to $+600{ }^{\circ} \mathrm{C}$, and included the determination of the homogenization temperatures of the fluid inclusions. The accuracy of measurements was $\pm 0.1{ }^{\circ} \mathrm{C}$ in the temperature interval from -20 to $+80{ }^{\circ} \mathrm{C}$ and $\pm 1{ }^{\circ} \mathrm{C}$ beyond this interval.

The investigations were carried out at the Analytical Center for multi-elemental and isotope research at the Siberian Branch of the Russian Academy of Science (Novosibirsk, Russia).

\section{Results}

\subsection{Mineralogy of REE-Carbonatites}

Detailed mineralogical information regarding Petyayan-Vara carbonatites is provided in the works of Kozlov et al. [16,30]. In this work, we considered only those mineral assemblages that were found in the carbonatites bearing REE hydrothermal mineralization and these became the subjects of the fluid regime study.

Dolomite is the most abundant carbonate mineral of Petyayan-Vara magnesiocarbonatites. The primary magmatic carbonatites, which are the protolith for all the considered rocks, contain Sr-containing dolomite with low concentrations of Fe and Mn. The primary dolomite (Dol-0) hosts submicron calcite, carbocernaite, and/or burbankite inclusions, as well as idiomorphic grains of magnetite (Figure 3a). The REE mineral assemblages in both ancylite and bastnäsite ores and hybrid carbonatites constitute the breccia matrix of primary magnesiocarbonatites, which are composed of primary dolomite. Also, the ancylite association is observed in the extensive dissolution cavities of primary carbonatites. In all cases, primary dolomite is shown to have undergone dissolution and recrystallization with the formation of several new generations of dolomite. In this case, primary dolomite became optically turbid and porous (Dol-1), while newly formed dolomite (Dol-2) typically showed a dense structure and optical transparency (Figure 3b). The present mineralogical and fluid inclusion investigations were performed on the newly formed dolomite. The mineral composition of the dolomite contains (wt.\%): FeO, 4.31-5.41; MnO, 0.19-2.11; MgO, 16.72-17.38; and SrO, below detection limits (Table 1).

Calcite is a secondary mineral. In the primary carbonatites of Petyayan-Vara, calcite is found only in the form of submicron inclusions in dolomite. In ancylite ores, calcite, together with quartz, is cemented by other minerals in the ancylite association and is the latest filling in the breccia matrix and dissolution cavities [15]. In the ancylite ores near the ancylite-rich regions, crystals of primary dolomite are partially or fully replaced by secondary calcite (Figure 3c). Near the ancylite ores, veins composed of giant-grained calcite are present. In all other Petyayan-Vara carbonatites (including bastnäsite 
ores and hybrid carbonatites), calcite and quartz \pm strontianite also occur in the latest phases in the mineralized fractures and dissolution cavities. The calcite comprises (wt.\%): MgO, 0.95-1.69; CaO, 54.26-55.91; and SrO, up to 0.28 (Table 1).

Ankerite either forms cross-cutting veins in the dolomitic matrix (Figure 3d) or replaces the dolomite (see Figure 3a), and also contains hydrothermal mineralization with hematite and REE mineral phases. The mineral composition of ankerite includes (wt.\%): CaO, 20.85-22.85; FeOt, 33.61-34.21; $\mathrm{MgO}, 0.73-2.04 ; \mathrm{MnO}$, up to 0.39; and SrO, up to 1.81 (see Table 1).

Siderite is a late carbonate mineral; it forms granular aggregates, and jointly with calcite, replaces the dolomite (Figure 3e,f). The mineral composition of siderite comprises (wt.\%): $\mathrm{CaO}, 0.73-2.55 ; \mathrm{MgO}$, 0.86-1.08; $\mathrm{MnO}, 0.27-0.44$; and FeOt, 57.59-60.52 (see Table 1).
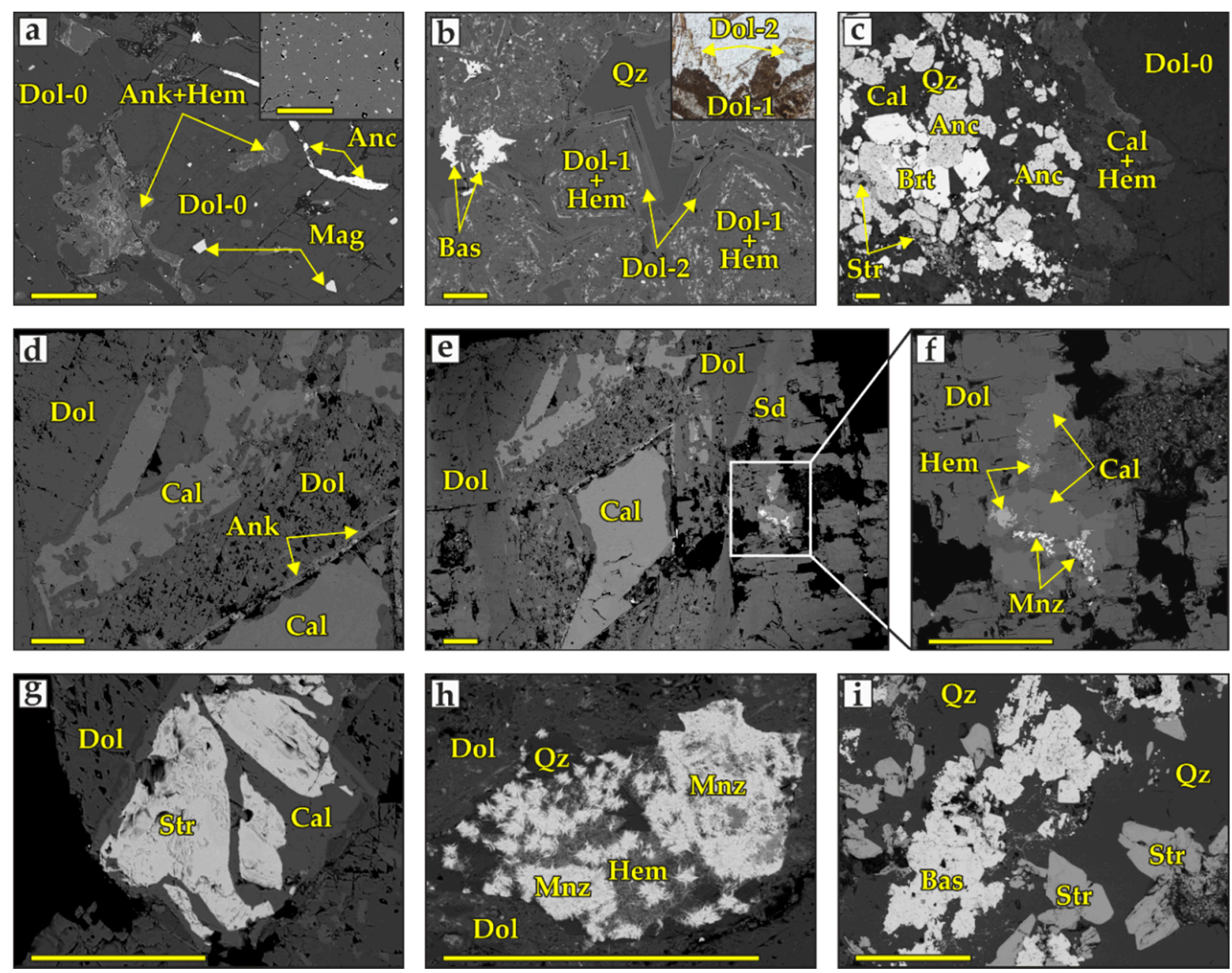

Figure 3. The mineralogy of Petyayan-Vara magnesiocarbonatites. (a) The early dolomite (Dol-0) with inclusions of magnetite (Mag), calcite (dark grey inclusions in the insert), carbocernaite and/or burbankite (light grey inclusions in the insert); locally replaced by ankerite (Ank) and hematite (Hem); and ancylite-(Ce) (Anc) in the interstices between Dol-0 grains. (b) Rims of the optically transparent dolomite with a dense structure (Dol-2) around the optically turbid porous dolomite (Dol-1), containing hematite; the remaining space is filled by quartz $(\mathrm{Qz})$ and bastnäsite-(Ce) (Bas); the insert shows the same in plane-polarized transmitted light. (c) Ancylite ore composed of ancylite-(Ce), baryte (Brt), early-generation strontianite (Str), calcite (Cal), and quartz; calcite and hematite jointly replace the Dol-0 near the border with ancylite ores. (d) Ankerite cross-cutting vein. (e,f) The replacement of dolomite by siderite (Sd) and calcite with micro-grain aggregates of hematite and monazite-(Ce) (Mnz). (g) Calcite with late strontianite. (h) The monazite-(Ce) forms needle mixture aggregates with hematite. (i) Microgranular aggregates of bastnäsite-(Ce) and hydroxylbastnäsite-(Ce) (Bas) surrounded by grains of quartz and late strontianite. All photomicrographs, except for the insertion in Figure 3b, were imaged in backscattered electron (BSE) mode. Scale bar is $200 \mu \mathrm{m}$ for all images. 
Table 1. The mineral composition of $\mathrm{Ca}-\mathrm{Mg}-\mathrm{Fe}-$ carbonates and $\mathrm{Ba}-\mathrm{Sr}-$ sulphates of the Petyayan-Vara "ancylite ores", “bastnäsite ores”, and hybrid rocks. Representative analyses (wt.\%).

\begin{tabular}{|c|c|c|c|c|c|c|c|c|}
\hline Mineral & $\mathrm{CaO}$ & $\mathrm{MgO}$ & $\mathrm{FeOt}$ & $\mathrm{MnO}$ & $\mathrm{SrO}$ & $\mathrm{BaO}$ & $\mathrm{SO}_{3}$ & Total \\
\hline \multirow[t]{3}{*}{ Dolomite } & 29.45 & 16.72 & 5.41 & 2.11 & b.d.l. & - & - & 53.65 \\
\hline & 28.73 & 17.38 & 4.63 & 1.14 & b.d.l. & - & - & 51.88 \\
\hline & 30.21 & 17.31 & 4.31 & 0.19 & b.d.l. & - & - & 52.02 \\
\hline \multirow[t]{3}{*}{ Calcite } & 55.91 & 0.95 & b.d.l. & b.d.l. & b.d.l. & - & - & 56.86 \\
\hline & 54.26 & 1.69 & 0.24 & b.d.l. & b.d.l. & - & - & 56.19 \\
\hline & 54.05 & 1.13 & b.d.l. & b.d.l. & 0.28 & - & - & 55.46 \\
\hline \multirow[t]{2}{*}{ Ankerite } & 22.85 & 2.04 & 34.21 & 0.19 & b.d.l. & - & - & 59.29 \\
\hline & 20.85 & 0.73 & 33.61 & 0.39 & 1.81 & - & - & 57.35 \\
\hline \multirow[t]{2}{*}{ Siderite } & 2.55 & 0.86 & 57.59 & 0.27 & b.d.l. & - & - & 61.27 \\
\hline & 0.73 & 1.08 & 60.52 & 0.44 & b.d.l. & - & - & 62.77 \\
\hline \multirow[t]{3}{*}{ Strontianite } & 1.04 & - & - & - & 68.62 & - & - & 69.64 \\
\hline & 2.53 & - & - & - & 66.63 & - & - & 69.16 \\
\hline & 0.62 & - & - & - & 69.04 & - & - & 69.66 \\
\hline \multirow[t]{2}{*}{ Celestite } & - & - & - & - & 52.48 & 3.98 & 42.88 & 99.34 \\
\hline & - & - & - & - & 47.02 & 8.97 & 43.08 & 99.07 \\
\hline \multirow[t]{2}{*}{ Baryte } & - & - & - & - & b.d.l. & 65.12 & 33.92 & 99.02 \\
\hline & - & - & - & - & 1.16 & 63.78 & 34.33 & 99.24 \\
\hline
\end{tabular}

Note for Tables 1 and 2: FeOt: total; b.d.l: below detection limits; -: not determined.

In the studied rocks, strontianite occupies two positions. First, it is one of the main minerals in ancylite ores, where its irregular grains are fused with baryte and ancylite and are syngenetic with them (see Figure 3c). Second, strontianite occurs as the late mineral in bastnäsite ores and hybrid carbonatites. In this case, it fills the space remaining after crystallization of quartz and bastnäsite and represents the late mineral in assemblages with calcite (Figure 3g). This strontianite is reportedly the product of the precipitation of $\mathrm{Sr}$ released upon dissolution of ancylite and its replacement with bastnäsite [15]. Strontianite contains 0.62-1.04 wt.\% of $\mathrm{CaO}$ (Table 1).

Baryte, together with ancylite and strontianite, is one of the main minerals in ancylite ores (see Figure 3c). In bastnäsite ores, baryte is an accessory mineral that present in minor amounts. In hybrid carbonatites, the formation of baryte follows the crystallization of the newly formed dolomite before the precipitation of ancylite, quartz with bastnäsite, and strontianite. Rare inclusions of micron grains and aggregates of celestite and baryte are also found in late calcite, ankerite, and quartz, as well as in the dolomitic matrix; the celestite mineral contains 3.98-8.97 wt.\% of $\mathrm{BaO}$ and the baryte composition includes up to $1.16 \mathrm{wt} . \%$ of $\mathrm{SrO}$ (see Table 1).

Ancylite-(Ce) is the main mineral in the ancylite assemblage (the ancylite ores) (see Figure 3c). It forms rhombic shaped idiomorphic crystals, which are overfilled with micro-inclusions of iron hydroxide and oxides and fused with first-generation baryte and strontianite. In bastnäsite ores, bastnäsite completely replaces the ancylite crystals with the formation of rhombic pseudomorphs. In hybrid carbonatites, the idiomorphic ancylite crystals are formed after baryte, but before quartz, with bastnäsite and late strontianite. In hybrid rocks, the ancylite is also replaced with polymineral quartz-bastnäsite pseudomorphs with ancylite relicts. The mineral composition of ancylite comprises (wt.\%): $\mathrm{CaO}, 0.54-0.91 ; \mathrm{La} / \mathrm{Ce}, 0.73-0.79$; and $\mathrm{La} / \mathrm{Nd}, 3.24-4.43$ (Table 2).

Monazite-(Ce) is crystallized as rare inclusions and micro-grain aggregates in late calcite veins and quartz; it forms assemblages and needle mixture aggregates with hematite (Figure 3f,h). Monazite contains (wt.\%): $\mathrm{CaO}, 3.48-4.41 ; \mathrm{SrO}, 4.08-5.04 ; \mathrm{ThO}_{2}$, up to 1.77; $\mathrm{SO}_{3}, 4.12-5.77 ; \mathrm{La} / \mathrm{Ce}, 0.51-0.55$; and $\mathrm{La} / \mathrm{Nd}, 1.71-1.79$ (Table 2). The lack of an $(\mathrm{OH})^{-}$group was confirmed by Raman data [15]. 
Table 2. The mineral composition of the rare earth element (REE) mineral phases of Petyayan-Vara "ancylite ores", "bastnäsite ores", and hybrid rocks. Representative analyses (wt.\%).

\begin{tabular}{|c|c|c|c|c|c|c|c|c|c|c|c|c|c|c|c|c|}
\hline Mineral & $\mathrm{CaO}$ & $\mathrm{SrO}$ & $\mathrm{La}_{2} \mathrm{O}_{3}$ & $\mathrm{Ce}_{2} \mathrm{O}_{3}$ & $\operatorname{Pr}_{2} \mathrm{O}_{3}$ & $\mathrm{Nd}_{2} \mathrm{O}_{3}$ & $\mathrm{Sm}_{2} \mathrm{O}_{3}$ & $\mathrm{ThO}_{2}$ & $\mathrm{P}_{2} \mathrm{O}_{5}$ & $\mathrm{SO}_{3}$ & $\mathbf{F}$ & $-\mathrm{O}=\mathrm{F}_{2}$ & $\mathrm{OH}$ & Total & $\mathrm{La} / \mathrm{Ce}$ & $\mathrm{La} / \mathrm{Nd}$ \\
\hline \multicolumn{17}{|c|}{ Ancylite-(Ce) } \\
\hline & 0.54 & 16.59 & 18.46 & 25.33 & 1.95 & 5.69 & 0.97 & b.d.l. & - & - & b.d.l. & - & - & 69.53 & 0.73 & 3.24 \\
\hline & 0.44 & 18.15 & 20.42 & 25.76 & 2.06 & 4.61 & b.d.l. & b.d.l. & - & - & b.d.l. & - & - & 71.44 & 0.79 & 4.43 \\
\hline & 0.91 & 15.83 & 20.09 & 25.38 & 1.65 & 4.86 & b.d.l. & b.d.l. & - & - & b.d.l. & - & - & 68.72 & 0.79 & 4.13 \\
\hline \multicolumn{17}{|c|}{ Bastnäsite-(Ce) } \\
\hline & 0.87 & b.d.l. & 20.31 & 35.47 & 3.04 & 9.16 & b.d.l. & b.d.l. & - & - & 6.02 & 2.54 & - & 74.86 & 0.57 & 2.22 \\
\hline & 1.09 & b.d.l. & 21.17 & 35.07 & 2.95 & 9.39 & b.d.l. & b.d.l. & - & - & 5.96 & 2.51 & - & 75.63 & 0.6 & 2.25 \\
\hline & 0.76 & b.d.l. & 20.79 & 36.33 & 3.04 & 9.18 & b.d.l. & b.d.l. & - & - & 5.36 & 2.26 & - & 75.46 & 0.57 & 2.26 \\
\hline \multicolumn{17}{|c|}{ Formulae based on the anions for the mineral } \\
\hline & 0.036 & & 0.294 & 0.509 & 0.043 & 0.128 & & & & & 0.996 & & 0.004 & & & \\
\hline & 0.045 & & 0.302 & 0.496 & 0.041 & 0.129 & & & & & 0.972 & & 0.028 & & & \\
\hline & 0.031 & & 0.296 & 0.513 & 0.043 & 0.126 & & & & & 0.872 & & 0.127 & & & \\
\hline \multicolumn{17}{|c|}{ Hydroxylbastnäsite-(Ce) } \\
\hline & 0.32 & b.d.l. & 20.35 & 36.61 & 2.61 & 8.82 & b.d.l. & b.d.l. & - & - & b.d.l. & - & - & 68.71 & 0.56 & 2.31 \\
\hline & 0.31 & b.d.l. & 20.86 & 36.74 & 2.75 & 8.83 & b.d.l. & b.d.l. & - & - & b.d.l. & - & - & 69.49 & 0.57 & 2.36 \\
\hline & 0.29 & b.d.l. & 20.85 & 36.63 & 2.81 & 8.89 & b.d.l. & b.d.l. & - & - & b.d.l. & - & - & 69.46 & 0.57 & 2.35 \\
\hline \multicolumn{17}{|c|}{ Formulae based on the anions for the mineral } \\
\hline & 0.013 & & 0.297 & 0.531 & 0.037 & 0.125 & & & & & & & - & & & \\
\hline & 0.013 & & 0.301 & 0.527 & 0.039 & 0.123 & & & & & & & - & & & \\
\hline & 0.012 & & 0.301 & 0.526 & 0.040 & 0.124 & & & & & & & - & & & \\
\hline \multicolumn{17}{|c|}{ Monazite-(Ce) } \\
\hline & 3.86 & 4.91 & 16.12 & 29.85 & 2.36 & 9.01 & 1.28 & 1.77 & 25.35 & 4.72 & - & - & - & 99.22 & 0.54 & 1.79 \\
\hline & 3.48 & 5.04 & 16.34 & 30.03 & 2.21 & 9.27 & b.d.l. & b.d.l. & 27.39 & 5.77 & - & - & - & 99.53 & 0.54 & 1.76 \\
\hline & 4.41 & 4.08 & 16.27 & 29.81 & 2.42 & 9.51 & b.d.l. & b.d.l. & 28.41 & 4.12 & - & - & - & 99.02 & 0.55 & 1.71 \\
\hline
\end{tabular}


Bastnäsite-(Ce) and hydroxylbastnäsite-(Ce) are minerals that coexist as part of single zonal crystals and aggregates of grains. Bastnäsite often forms the core and hydroxylbastnäste forms a border around the bastnäsite. Hydroxylbastnäsite is much more common in the carbonates of Petyayan-Vara than bastnäsite; the minerals form fine impregnations in the dolomitic matrix, as well as the microgranular aggregates in quartz and calcite (Figure $3 b, i$ ). Both minerals are found in all of the studied varieties of carbonatites. In ancylite ores, they are present in minor amounts and compose small tabular intergrowths with synchisite-(Ce) in quartz, cementing the minerals of the ancylite association. In bastnäsite ores and hybrid carbonatites, these are the main minerals of REEs. In bastnäsite ores, elongated crystals of bastnäsite and hydroxylbastnäsite form semispherical aggregates overgrown with quartz. In hybrid rocks, these minerals are part of the ancylite pseudomorphs and form needle crystals and sponge aggregates in the quartz matrix. The bastnäsite-(Ce) comprises (wt.\%): $\mathrm{CaO}$, 0.76-1.09; F, 5.36-6.02; La/Ce, 0.57-0.60; and La/Nd, 2.22-2.26 (Table 2). Hydroxylbastnäsite-(Ce) includes (wt.\%): $\mathrm{CaO}, 0.29-0.32 ; \mathrm{La} / \mathrm{Ce}, 0.56-0.57$; and the mineral differs from bastnäsite-(Ce) due to its slightly higher La/Nd ratio of 2.31-2.36 and an F concentration below the detection limit due to the predominant $\mathrm{OH}$ content. The diagnosis of the bastnäsite and hydroxylbastnäsite was verified by Raman spectroscopy [15].

Quartz is an extremely late mineral, and it is widely distributed in the studied types of dolomitic carbonatites (Figure $3 b, c, f, h, i)$. In ancylite ores, the late pore-filling quartz cements the minerals of the ancylite association and contains many inclusions of baryte, celestine, and calcite. In bastnäsite ores, the breccia matrix is composed of quartz, bastnäsite, and/or hydroxybastnäsite. In hybrid carbonatites, granular quartz together with bastnäsite/hydroxylbastnäsite, fills most of the cavity space remaining after the crystallization of baryte and ancylite-(Ce).

\subsection{Fluid Inclusion Study}

Fluid inclusions were studied in quartz, calcite, and dolomite crystals and granular aggregates containing the late hydrothermal ore-related Ba-Sr-REE (sulphate, carbonate, and hydrocarbonate) mineralization of the above-described Petyayan-Vara dolomitic carbonatites (Figures 2 and 3). Four types of fluid inclusions were identified under the microscope [31]: primary highly concentrated crystal-fluid inclusions in quartz and calcite (type-i), secondary and pseudo-secondary highly concentrated (type-ii), and medium concentrated (type-iii) crystal-fluid inclusions in quartz and carbonates; and abundant gas-liquid primary and secondary fluid inclusions in dolomite, calcite, and quartz (type-iv) (Figure 4).

The primary crystal-fluid inclusions in quartz and calcite (type-i) are located singly and in groups of 2-3 inclusions in the central parts and growth zones of the matrix minerals. These inclusions have rounded or irregular shapes in the polished sections. They contain the gaseous phase ( $2-4$ vol.\%), the liquid phase, and 1-3 solid anisotropic crystal phases (Figure 4a). The crystal phases occupy more than $75 \%$ of the volume of the inclusions, and the inclusions are referred to as highly concentrated fluids. The size of the fluid inclusions ranges between 5 and $20 \mu \mathrm{m}$. Raman spectroscopy revealed the presence of $\mathrm{CO}_{2}$ in the gaseous phase and the daughter phases are represented by thenardite $\left(\mathrm{Na}_{2} \mathrm{SO}_{4}\right)$ and/or anhydrite $\left(\mathrm{CaSO}_{4}\right)$ (Figure 5a). According to the thermometric data, the inclusions homogenized at temperatures of $300-350{ }^{\circ} \mathrm{C}$ and the gas bubble dissolved in the interval of $290-300^{\circ} \mathrm{C}$ (Figure 6). The concentration of such fluids is estimated as more than $50 \mathrm{wt} . \%$ at a pressure of more than 1000 bar [32]; the pressure was assumed from geological data [7].

The secondary and pseudo-secondary highly concentrated fluid inclusions in quartz and dolomite fill the planes and cracks within the matrix grains (Figure $4 \mathrm{~b}$ ). These fluid inclusions have an isometric form in the plane and are about 5-15 $\mu \mathrm{m}$ in diameter. They contain the $\mathrm{CO}_{2}$ gaseous phase (1-2 vol.\%), the liquid phase, and 1-3 solid anisotropic crystal daughter phases (40-65 vol.\%) of synchysite-(Ce) $\left(\mathrm{Ca}(\mathrm{Ce}, \mathrm{La})\left(\mathrm{CO}_{3}\right)_{2} \mathrm{~F}\right)$ and/or shortite $\left(\mathrm{Na}_{2} \mathrm{Ca}_{2}\left(\mathrm{CO}_{3}\right)_{3}\right)$ (Figure $\left.5 \mathrm{~b}\right)$, sometimes with the presence of xenogenic crystals of dolomite and monazite-(Ce). The concentrated type-ii crystal-fluid inclusions show a homogenization temperature interval of $225-280^{\circ} \mathrm{C}$ (Figure 6); the daughter crystal phases 
are usually dissolved at $250-275^{\circ} \mathrm{C}$. The total concentration of the fluid inclusions (type-ii) could be estimated as no less than $40-45 \mathrm{wt}$ \% for the idealized $\mathrm{Na}_{2} \mathrm{CO}_{3}-\mathrm{H}_{2} \mathrm{O}$ system at the pressure of 1000-1500 bar [33].
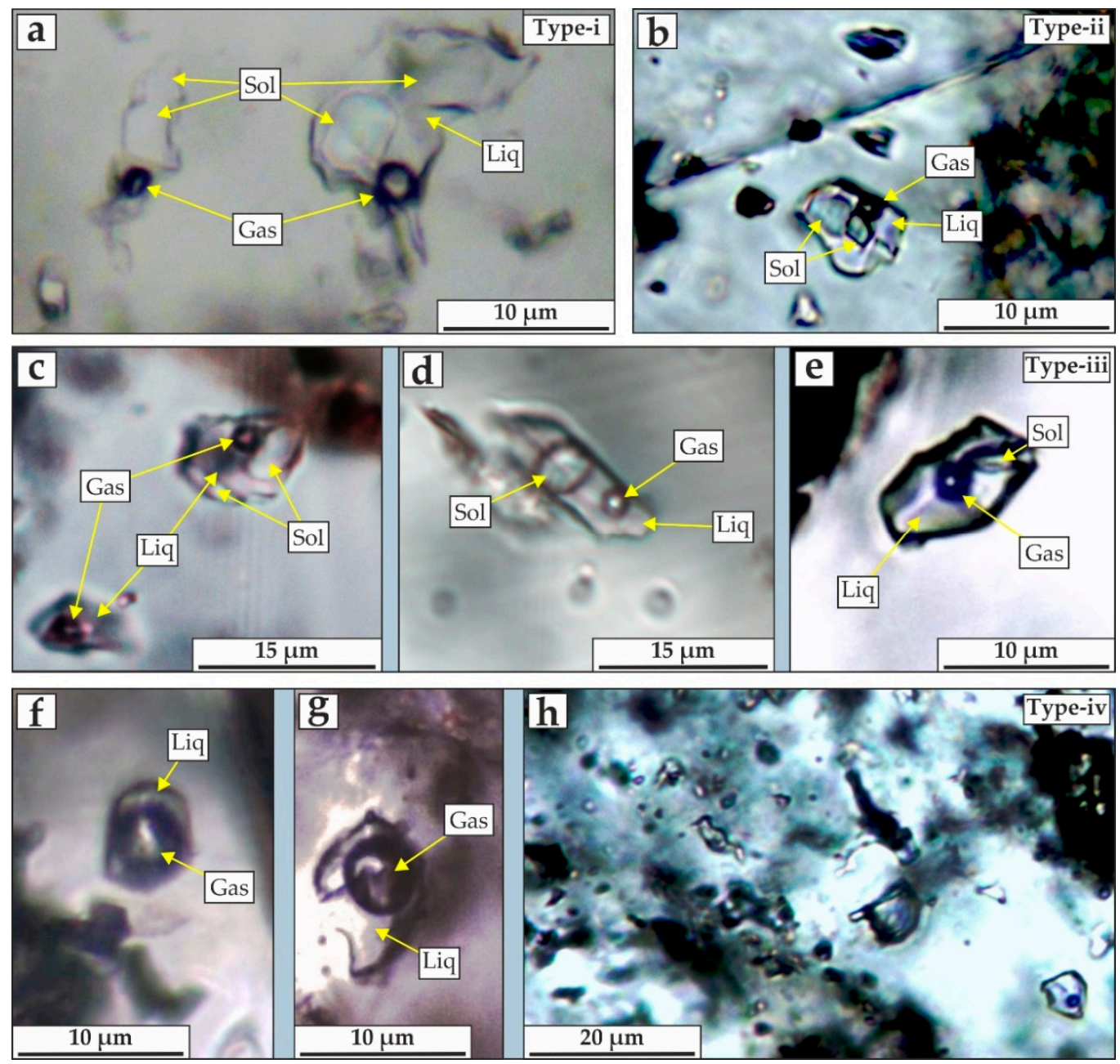

Figure 4. Fluid inclusions of the ore-related REE late-stage hydrothermal mineralization of Petyayan-Vara magnesiocarbonatites. (a) Primary highly concentrated type-i crystal-fluid inclusions in quartz and calcite; (b) type-ii secondary and pseudo-secondary highly concentrated inclusions; (c-e) type-iii medium concentrated crystal-fluid inclusions in quartz and carbonates; type-iv gas-liquid primary $(\mathbf{f}, \mathbf{g})$, and secondary (h) fluid inclusions in carbonate and quartz. Sol, solid; Liq, liquid.

The next type of crystal-fluid inclusion (type-iii) is represented by the secondary fluids in the calcite, quartz, and late dolomitic veins containing the hydrothermal mineralization (Figure 4c-e). The fluid inclusions have an elongated or irregular shape and consist of the $\mathrm{CO}_{2}$ gaseous phase (1-2 vol.\%), the liquid phase, and 1-2 crystal daughter phases of $\mathrm{Na}$ and $\mathrm{Ca}$ hydrocarbonates (10-15 vol.\%): nahcolite $\left(\mathrm{NaHCO}_{3}\right)$ and/or gaylussite $\left(\mathrm{Na}_{2} \mathrm{Ca}\left(\mathrm{CO}_{3}\right)_{2} \cdot 5 \mathrm{H}_{2} \mathrm{O}\right)$ (Figure $5 \mathrm{~d}$,e), as well as halite $(\mathrm{NCl})$ cubic crystals.

The type-iii fluid inclusions were homogenized at $190-250{ }^{\circ} \mathrm{C}$ with the dissolving of the crystal phase at $140-220^{\circ} \mathrm{C}$. The salt concentration of such fluids was estimated according to the thermo-freezing investigations: an ice melting temperature of $-10 \pm 1^{\circ} \mathrm{C}$, an eutectic melting temperature of -21 to $-22{ }^{\circ} \mathrm{C}$, and a nahcolite melting temperature of $145 \pm 5^{\circ} \mathrm{C}$. In this way, according to the ternary $\mathrm{NaHCO}_{3}-\mathrm{NaCl}-\mathrm{H}_{2} \mathrm{O}$ system diagram, the concentration of the crystalline phases in the fluid inclusions is 20-21 wt.\% of $\mathrm{NaHCO}_{3}$ and 10-11 wt.\% of $\mathrm{NaCl}$ [34]. 
The last type of fluid inclusion (type-iv) occurs when the gas-liquid secondary fluids occupy the late veins, planes, and fractures in the late hydrothermal carbonates and quartz cross-cutting the Ba-Sr- and REE-containing mineral aggregates (Figure $4 \mathrm{f}-\mathrm{h}$ ). They have a rounded and irregular shape, contain the gas $\mathrm{CO}_{2}$ and liquid phases in different concentrations, and the size of the fluid inclusion varies from 5 to $15 \mu \mathrm{m}$. The concentration of such fluids is estimated as $5-15 \mathrm{wt}$. $\%$ of $\mathrm{NaCl}-\mathrm{equ}$. (relatively low-concentrated, with eutectic temperatures of -10 to $-5{ }^{\circ} \mathrm{C}$ [31]). The homogenization temperature range of the type-iv gas-liquid fluid inclusions is between $150-200{ }^{\circ} \mathrm{C}$ (Figure 6).
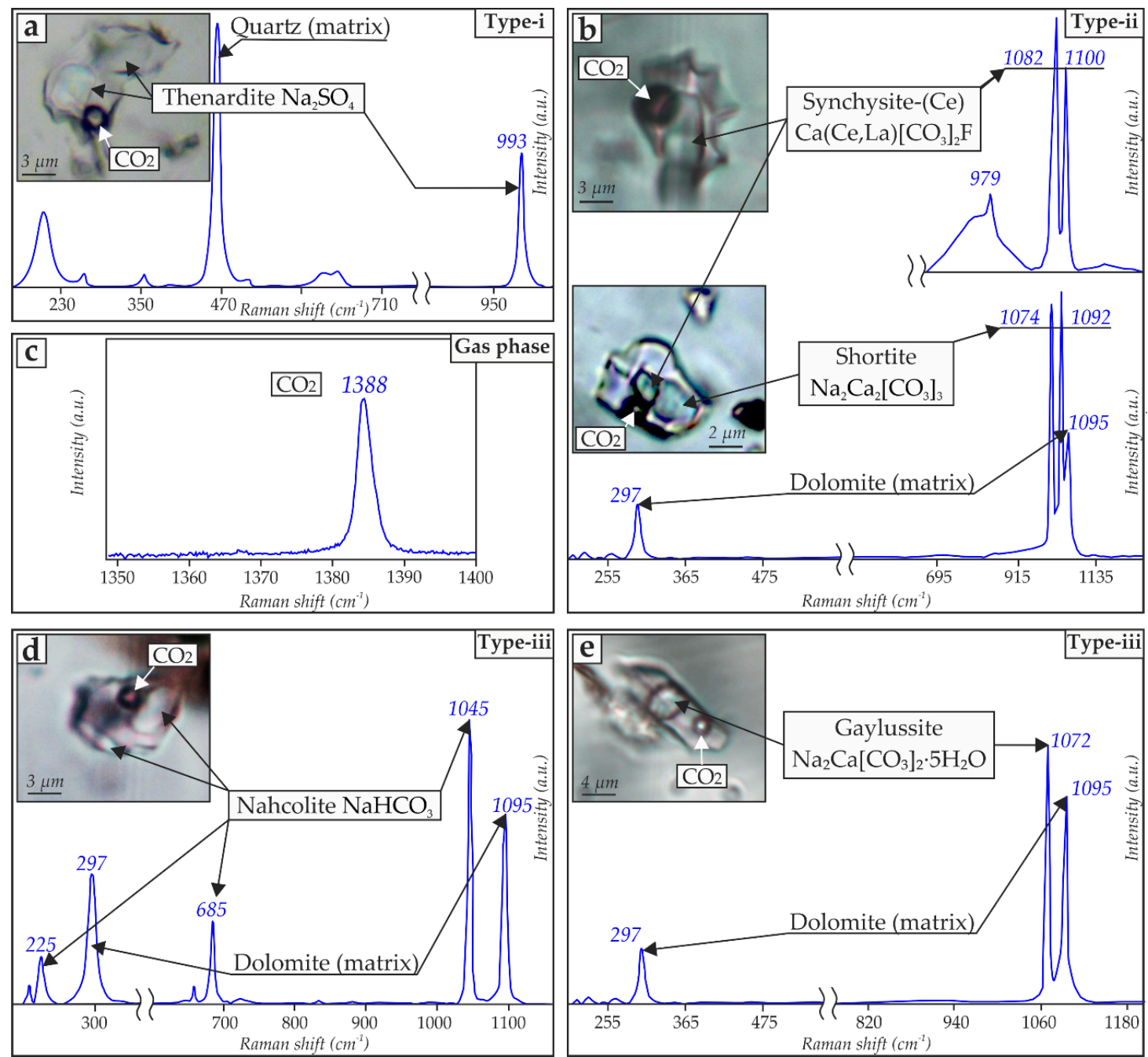

Figure 5. Raman data of the fluid inclusion investigations of the ore-related REE late-stage hydrothermal mineralization of Petyayan-Vara magnesiocarbonatites. (a) Photomicrographs and the spectra of thenardite daughter phases in type-i fluid inclusions in quartz; (b) photomicrographs of the type-ii fluid inclusions with the spectra of synchysite-(Ce) and shortite daughter phases in the dolomitic matrix; (c) the spectrum of the $\mathrm{CO}_{2}$ gaseous phase of the fluid inclusions; photomicrographs of the type-iii fluid inclusions and the spectra of crystal daughter phases of (d) nahcolite and (e) gaylussite in the dolomitic matrix. 


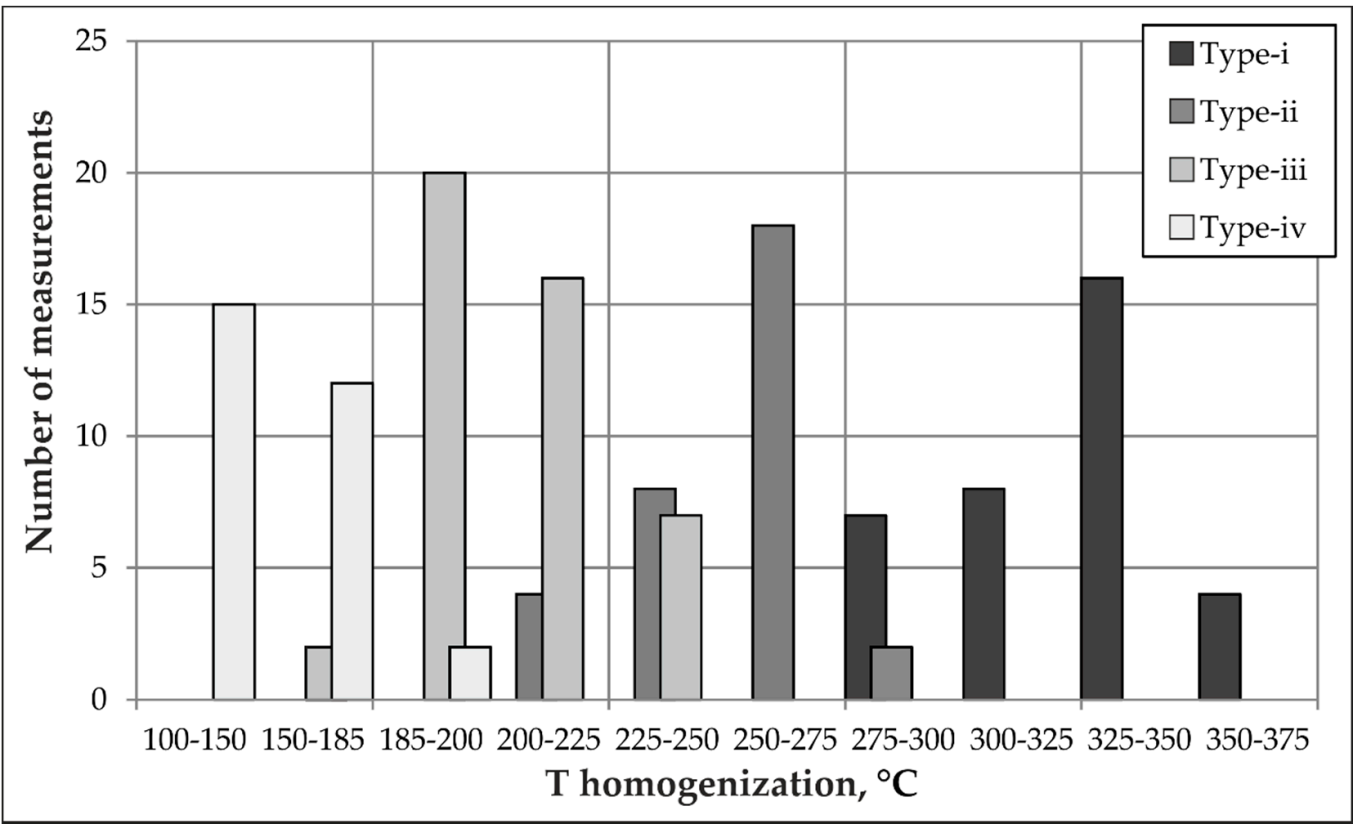

Figure 6. Thermometric data of the fluid inclusion investigations of the ore-related $\mathrm{Ba}-\mathrm{Sr}$ and REE hydrothermal mineralization of Petyayan-Vara magnesiocarbonatites.

\section{Discussion}

Carbonatites are a unique group of magmatic rocks, distinguished by extremely high concentrations and the world's largest reserves of rare earth elements, niobium and a number of other rare metals [2-4]. The REE enrichment of carbonatites can be explained by fractional crystallization processes as well as orthomagmatic fluids activity during the late magmatic events, which results in the REE being concentrated in the latter hydrothermal-metasomatic stages [2-4,18-29]. Although the magmatic processes play an important role in concentrating the rare metals in carbonatites, recent data [3] has shown that significant enrichment with rare-earth elements occurs at the final stages of evolution of carbonatite systems. The late-stage hydrothermal REE enrichment can be traced in the mineral and fluid inclusion composition evolution for many carbonatite complexes, e.g., the Mianning-Dechang REE-carbonatite belt in SW China [18-21,23,25], the fluorite-REE rocks of the Mushgai-Khudag alkaline complex in South Mongolia [24] and the Songwe Hill REE-carbonatites in Malawi [28]. Below, we detail the process of accumulation and redistribution of rare earth elements and ore-related components in the late stages of the evolution of the Petyayan-Vara carbonatite system.

Previous studies of Petyayan-Vara burbankite-bearing dolomite carbonatites [16] have shown their primary igneous origin. These rocks have been exposed to the intense processes of hydrothermal-metasomatic alteration, which is reflected in the evolution of mineral parageneses [16]. During these processes, REE, Th, and other components were repeatedly redeposited. The fluids involved in REE transport and deposition are characterized by the high activity of ligands $(\mathrm{F}, \mathrm{Cl}$, $\left.\mathrm{CO}_{2}(\mathrm{~L}), \mathrm{SO}_{4}\right)$ and brines (e.g., $\left.\mathrm{NaCl}\right)$ (e.g., [35-37]). This is supported by the fluid inclusion data and mineralogical observations for many carbonatite complexes $[4,5,24,26,29,38-45]$. In a study of mineral paragenesis [16], it was hypothesized that it was such a fluid that caused the formation of REE ores in Petyayan-Vara. A description of the evolution of this fluid at the late magmatic and (carbo)-hydrothermal stages of the formation of carbonatites was also proposed. The fluid inclusion data obtained in this study confirm these assumptions and provide additional information on the composition and temperature conditions of the fluids responsible for successive mineral formation.

As stated in [16], a sulfur-rich fluid caused the decomposition of burbankite from primary magmatic carbonatites, thereby accumulating $\mathrm{Sr}, \mathrm{Ba}$, and REE, and then re-deposited these elements into the cracks and crush zones. This was the main stage of REE concentration in Petyayan-Vara, 
during which ancylite ores (baryte-strontianite-ancylite mineralization) were formed. As shown by Andersen et al. [46], the fluids responsible for the burbankite to ancylite conversion are predominantly magmatic. The magmatic fluid that caused the decomposition of burbankite and the redeposition of REE into ancylite was probably highly concentrated ( $>50 \mathrm{wt} . \%)$ sulphate fluid, which was trapped in the type-i fluid inclusions. This fluid includes $\mathrm{Na}^{+}, \mathrm{SO}_{4}{ }^{2-}$, and $\mathrm{H}_{2} \mathrm{O}-\mathrm{CO}_{2}$ with minor $\mathrm{Ca}^{2+}$ (thenardite, the predominant daughter phase of type-i fluid inclusions). Thus, as follows from the homogenization temperature of type-i fluid inclusions, the temperature was $325 \pm 25^{\circ} \mathrm{C}$ at the initial stage of the formation of ancylite ores.

In the formation of ancylite ores, the fluid phase was depleted in REE, $\mathrm{Sr}, \mathrm{Ba}$, and $\mathrm{S}$ due to the precipitation of strontianite, ancylite, and baryte. Simultaneously, the activity of calcium $\left(a \mathrm{Ca}^{2+}\right)$ increased, as evidenced by the small tabular intergrowths of bastnäsite-(Ce) with synchysite-(Ce) in quartz, cementing the minerals of the ancylite assemblage [28,47-51]. An increase in $a \mathrm{Ca}^{2+}$ is also indicated by the replacement of dolomite with calcite near the ancylite-rich areas (see Figure 3c). At this stage of mineral formation, the processes likely produced the type-ii fluid inclusions, which were evidenced by the presence of a synchysite daughter phase in these inclusions. Thus, the final ancylite ore-related stages were characterized by concentrated (40-45 wt.\%) carbonate fluids of $\mathrm{Ca}^{2+}$, $\mathrm{Na}^{+}, \mathrm{REE}^{3+}, \mathrm{F}^{-}$, and $\mathrm{H}_{2} \mathrm{O}-\mathrm{CO}_{2}$ composition (shortite and synchysite daughter phases, type-ii fluid inclusions). The alteration of the fluid chemistry from sulfate to carbonate is a typical consequence of a decrease in sulfur concentration due to baryte crystallization. The homogenization temperatures of type-ii fluid inclusions show that the final-stage formation of ancylite ores occurred at temperatures of $250 \pm 25^{\circ} \mathrm{C}$ or higher. According to [16], ancylite was replaced by bastnäsite and monazite. Bastnäsite was deposited from the fluid prior to synchysite, as deduced from the character of their intergrowth. The REE fluorocarbonates crystallized due to $\mathrm{Sr}$ deficiency, resulting from the abundant crystallization of strontianite, celestine, and ancylite. The presence of xenogenic monazite crystals in type-ii fluid inclusions suggests that this mineral was at least partly formed before the completion of the ancylite ore formation. Monazite formed along with thorite, both of which accumulated heavy rare earth elements [16]. Thus, at the final formation stages, the intense mineralization of ancylite ores evolved due to auto-metasomatic processes under the influence of residual fluids.

The main REE host mineral in bastnäsite ores is not bastnäsite but hydroxylbastnäsite. This suggests low fluorine activity and high $(\mathrm{OH})^{-}$activity in the parental silica-rich fluid [16]. Also, the absence of sulfur in the bastnäsite ores proves that this component did not significantly contribute to REE mobility during the later hydrothermal stages [16]. Fluid inclusion investigations conducted in this study found that for late-stage ore-related REE hydrothermal processes, the low-concentrated (20-30 wt.\%) chloride-hydrocarbonate fluids of $\mathrm{Ca}^{2+}, \mathrm{Na}^{+}, \mathrm{HCO}_{3}{ }^{-}, \mathrm{Cl}^{-}$, and $\mathrm{H}_{2} \mathrm{O}-\mathrm{CO}_{2}$ composition (nahcolite, gaylussite, and halite daughter phases, type-iii fluid inclusions) were responsible. Based on the mineral paragenesis related to this fluid, the latter was also rich in $\mathrm{Si}$ and Fe. The homogenization temperatures of type-iii fluid inclusions show that the lowest crystallization temperature for hydroxylbastnäsite, siderite, hematite, and the bulk of quartz was $220 \pm 30^{\circ} \mathrm{C}$.

The latest hydrothermal mineralization is characterized by the relatively low-concentrated ( $<15 \mathrm{wt} . \%$ of $\mathrm{NaCl}$-equ.) chloride fluids composed of $\mathrm{NaCl}-\mathrm{H}_{2} \mathrm{O}-\mathrm{CO}_{2}$ and a temperature of $200-150{ }^{\circ} \mathrm{C}$.

Therefore, the mineralogical and fluid inclusion investigations of the carbonatite complexes show that the processes of REE accumulation and redistribution are controlled by the fluid activity. The orthomagmatic fluids evolved from carbonatite magmas are usually $\mathrm{Na}-\mathrm{K}$-chloride-carbonate/bicarbonate brines and have variable salt contents [52]. Sulfate, phosphate, and fluoride components may also be high $[5,24-26,38-45,52]$. $\mathrm{Cl}^{-}$and $\mathrm{SO}_{4}{ }^{2-}$ are usually the dominant anions with minor $\mathrm{CO}_{3}{ }^{2-}$ and $\mathrm{HCO}_{3}{ }^{-} . \mathrm{K}^{+}, \mathrm{Na}^{+}$, and $\mathrm{Ca}^{2+}$ are the dominant cations with levels of $\mathrm{Fe}, \mathrm{Sr}, \mathrm{Ba}, \mathrm{REE}$, etc. Nahcolite is a common daughter phase, and some other sulfate daughter phases such as arcanite, mirabilite, thenardite, gaylussite, anhydrite, celestine and baryte occur in the ore-forming fluids $[5,24,25,38-45,52,53]$. The sulphate-carbonate-chloride composition of the ore-forming fluids has been revealed, for example, for the Maoniuping REE-carbonatites (China) [25], 
the Mushgai-Khudag REE-F-Ba-Sr-P carbonatite complex (Mongolia) [24], the Fe-F-REE carbonatites of the Central-Tuva [44], and the Ba-Sr carbonatites of the Western Transbaikalia [38] regions, as well as for the alkali-basic, alkaline, and lamproite complexes of the Aldan and Altay regions in the Russian Siberia [26,53].

The oxidized state of the ore-forming orthomagmatic fluids should be noted [53]. The specific feature of the ore-forming fluids of Petyayan-Vara carbonatites is the predominantly carbonate-hydrocarbonate composition for REE late-stage hydrothermal mineralization. The presented data are consistent with those on carbonatite complexes around the world and complement the information available about the TX-parameters and the mechanism of REE hydrothermal mineralization of magnesiocarbonatites from the Vuoriyarvi alkaline complex of the Kola Alkaline Province.

\section{Conclusions}

1. The Petyayan-Vara magnesiocarbonatites underwent intense hydrothermal-metasomatic processes. The Ba-Sr and REE ore-related late-stage hydrothermal mineralization is represented by the ancylite-baryte-strontianite-celestine-calcite-quartz ( \pm late Ca-Fe-Mg carbonates), with monazite-(Ce)-bastnäsite-(Ce)-thorite, and hydroxylbastnäsite-(Ce) mineral assemblages.

2. The ore-forming late-stage hydrothermal fluids wee oxidized and elemental compositions evolved, which resulted in auto-metasomatic alteration and recrystallization. The fluid regime was changed from highly concentrated (30-50 wt.\%) sulphate-carbonate at $275-300{ }^{\circ} \mathrm{C}$ to medium-low concentrated ( $<15 \mathrm{wt}$. \% of NaCl-equ.) hydrocarbonate-chloride at $150-250{ }^{\circ} \mathrm{C}$.

3. The REE-late-stage hydrothermal mineralization of Petyayan-Vara magnesiocarbonatites is most likely a product of hydrothermal-metasomatic remobilization of the REE mineral phases by the high activity of the sulphate-carbonate-hydrocarbonate-chloride hydrothermal ore-forming fluids.

Author Contributions: Conceptualization, I.P. and E.K.; methodology, I.P. and E.K.; field research and provision of study materials, E.K., E.F., and M.D.; data curation and validation, A.D.; investigation, I.P. and M.D.; writing-original draft, I.P.; writing-review and editing, A.D., E.K., and E.F. All authors have read and agreed to the published version of the manuscript.

Funding: Field research for this study was carried out at the Geological Institute KSC RAS under the state order \#0226-2019-0053. Fluid inclusion investigations were supported by the Russian Science Foundation (RSF), project \#19-77-10039. The SEM and EPMA analyses of the mineral phases were supported by the RSF project \#19-17-00013.

Acknowledgments: The authors express their sincere appreciation to the editor and anonymous reviewers for their contributions to improve the manuscript. Analytical equipment for this study was provided by the Analytical Center for multi-elemental and isotope research of the Sobolev Institute of Geology and Mineralogy SB RAS, and the work was done on state assignment of IGM SB RAS (\#0330-2016-0002).

Conflicts of Interest: The authors declare no conflict of interest.

\section{References}

1. Le Maitre, R.W.; Streckeisen, A.; Zanettin, B.; Le Bas, M.J.; Bonin, B.; Bateman, P.; Bellieni, G.; Dudek, A.; Efremova, S.; Keller, J.; et al. Igneous Rocks, 2nd ed.; Le Maitre, R.W., Streckeisen, A., Zanettin, B., Le Bas, M.J., Bonin, B., Bateman, P., Eds.; Cambridge University Press: Cambridge, UK, 2002; ISBN 9780511535581.

2. Weng, Z.; Jowitt, S.M.; Mudd, G.M.; Haque, N. A detailed assessment of global rare earth element resources: Opportunities and challenges. Econ. Geol. 2015, 110, 1925-1952. [CrossRef]

3. Chakhmouradian, A.R.; Wall, F. Rare earth elements: Minerals, mines, magnets (and more). Elements 2012, 8, 333-340. [CrossRef]

4. Wall, F. Rare earth elements. In Critical Metals Handbook; John Wiley \& Sons: Oxford, UK, 2013; pp. 312-339, ISBN 9780470671719.

5. Goodenough, K.M.; Wall, F.; Merriman, D. The rare earth elements: Demand, global resources, and challenges for resourcing future generations. Nat. Resour. Res. 2018, 27, 201-216. [CrossRef] 
6. Kalashnikov, A.O.; Konopleva, N.G.; Pakhomovsky, Y.A.; Ivanyuk, G.Y. Rare earth deposits of the Murmansk region, Russia-A review. Econ. Geol. 2016, 111, 1529-1559. [CrossRef]

7. Kukharenko, A.A.; Orlova, M.P.; Bulakh, A.G.; Bagdasarov, E.A.; Rimskaya-Korsakova, O.M.; Nefedov, Y.I.; II'inskii, G.A.; Sergeev, A.S.; Abakumova, N.B. The Caledonian Complex of Ultrabasic and Alkaline Rocks and Carbonatites of the Kola Peninsula and Northern Karelia; Nedra: Moscow, Russia, 1965. (In Russian)

8. Gerasimovsky, V.I.; Volkov, V.P.; Kogarko, L.M.; Polyakov, A.I. Kola peninsula. In The Alkaline Rocks; Sørensen, H., Ed.; John Wiley \& Sons: New York, NY, USA, 1974; pp. 206-220, ISBN 9780471813835.

9. Kramm, U.; Kogarko, L.N.; Kononova, V.A.; Vartiainen, H. The Kola Alkaline Province of the CIS and Finland: Precise Rb-Sr ages define 380-360 Ma age range for all magmatism. Lithos 1993, 30, 33-44. [CrossRef]

10. Arzamastsev, A.A.; Glaznev, V.N.; Arzamastseva, L.V.; Bea, F.; Montero, P. Kola alkaline province in the Paleozoic: Evaluation of primary mantle magma composition and magma generation conditions. Russ. J. Earth Sci. 2001, 3, 1-32. [CrossRef]

11. Bulakh, A.G.; Ivanikov, V.V.; Orlova, M.P. Overview of carbonatite-phoscorite complexes of the Kola Alkaline Province. In Phoscorites and Carbonatites from Mantle to Mine; Wall, F., Zaitsev, A.N., Eds.; Mineralogical Society of Great Britain and Ireland: London, UK, 2004; pp. 1-43, ISBN 9780903056229.

12. Downes, H.; Balaganskaya, E.; Beard, A.; Liferovich, R.; Demaiffe, D. Petrogenetic processes in the ultramafic, alkaline and carbonatitic magmatism in the Kola Alkaline Province: A review. Lithos 2005, 85, 48-75. [CrossRef]

13. Arzamastsev, A.A.; Mitrofanov, F.P. Paleozoic plume-lithospheric processes in northeastern Fennoscandia: Evaluation of the composition of the parental mantle melts and magma generation conditions. Petrology 2009, 17, 300-313. [CrossRef]

14. Rukhlov, A.S.; Bell, K. Geochronology of carbonatites from the Canadian and Baltic Shields, and the Canadian Cordillera: Clues to mantle evolution. Mineral. Petrol. 2010, 98, 11-54. [CrossRef]

15. Afanasyev, B.V. Mineral Resources of the Alkaline-Ultramafic Massifs of the Kola Peninsula; Roza Vetrov: St. Petersburg, Russia, 2011. (In Russian)

16. Kozlov, E.; Fomina, E.; Sidorov, M.; Shilovskikh, V.; Bocharov, V.; Chernyavsky, A.; Huber, M. The Petyayan-Vara Carbonatite-Hosted Rare Earth Deposit (Vuoriyarvi, NW Russia): Mineralogy and Geochemistry. Minerals 2020, 10, 73. [CrossRef]

17. Sun, J.; Zhao, J.; Chen, J.; Keisuke, N.; Hirochika, S.; Shen, K.; Men, L.; Chen, L. Ore-forming mechanism for the Xiaoxinancha Au-rich Cu deposit in Yanbian, Jilin Province, China: Evidence from noble gas isotope geochemistry of fluid inclusions in minerals. Sci. China Ser. D Earth Sci. 2008, 51, 216-228. [CrossRef]

18. Zheng, X.; Liu, Y. Mechanisms of element precipitation in carbonatite-related rare-earth element deposits: Evidence from fluid inclusions in the Maoniuping deposit, Sichuan Province, southwestern China. Ore Geol. Rev. 2019, 107, 218-238. [CrossRef]

19. Guo, D.; Liu, Y. Occurrence and geochemistry of bastnäsite in carbonatite-related REE deposits, Mianning-Dechang REE belt, Sichuan Province, SW China. Ore Geol. Rev. 2019, 107, 266-282. [CrossRef]

20. Cangelosi, D.; Smith, M.; Banks, D.; Yardley, B. The role of sulfate-rich fluids in heavy rare earth enrichment at the Dashigou carbonatite deposit, Huanglongpu, China. Mineral. Mag. 2020, 84, 65-80. [CrossRef]

21. Liu, Y.; Chakhmouradian, A.R.; Hou, Z.; Song, W.; Kynický, J. Development of REE mineralization in the giant Maoniuping deposit (Sichuan, China): Insights from mineralogy, fluid inclusions, and trace-element geochemistry. Miner. Depos. 2019, 54, 701-718. [CrossRef]

22. Samson, I.M.; Wood, S.A.; Finucane, K. fluid inclusion characteristics and genesis of the fluorite-parisite Mineralization in the Snowbird Deposit, Montana. Econ. Geol. 2004, 99, 1727-1744. [CrossRef]

23. Shu, X.; Liu, Y. Fluid inclusion constraints on the hydrothermal evolution of the Dalucao Carbonatite-related REE deposit, Sichuan Province, China. Ore Geol. Rev. 2019, 107, 41-57. [CrossRef]

24. Nikolenko, A.M.; Redina, A.A.; Doroshkevich, A.G.; Prokopyev, I.R.; Ragozin, A.L.; Vladykin, N.V. The origin of magnetite-apatite rocks of Mushgai-Khudag Complex, South Mongolia: Mineral chemistry and studies of melt and fluid inclusions. Lithos 2018, 320-321, 567-582. [CrossRef]

25. Xie, Y.; Hou, Z.; Yin, S.; Dominy, S.C.; Xu, J.; Tian, S.; Xu, W. Continuous carbonatitic melt-fluid evolution of a REE mineralization system: Evidence from inclusions in the Maoniuping REE Deposit, Western Sichuan, China. Ore Geol. Rev. 2009, 36, 90-105. [CrossRef] 
26. Prokopyev, I.R.; Doroshkevich, A.G.; Ponomarchuk, A.V.; Sergeev, S.A. Mineralogy, age and genesis of apatite-dolomite ores at the Seligdar apatite deposit (Central Aldan, Russia). Ore Geol. Rev. 2017, 81, $296-308$. [CrossRef]

27. Liu, Y.; Hou, Z. A synthesis of mineralization styles with an integrated genetic model of carbonatite-syenite-hosted REE deposits in the Cenozoic Mianning-Dechang REE metallogenic belt, the eastern Tibetan Plateau, southwestern China. J. Asian Earth Sci. 2017, 137, 35-79. [CrossRef]

28. Broom-Fendley, S.; Brady, A.E.; Wall, F.; Gunn, G.; Dawes, W. REE minerals at the Songwe Hill carbonatite, Malawi: HREE-enrichment in late-stage apatite. Ore Geol. Rev. 2017, 81, 23-41. [CrossRef]

29. Prokopyev, I.R.; Doroshkevich, A.G.; Redina, A.A.; Obukhov, A.V. Magnetite-apatite-dolomitic rocks of Ust-Chulman (Aldan shield, Russia): Seligdar-type carbonatites? Mineral. Petrol. 2018, 112, 257-266. [CrossRef]

30. Kozlov, E.; Fomina, E.; Sidorov, M.; Shilovskikh, V. Ti-Nb mineralization of late carbonatites and role of fluids in its formation: Petyayan-vara rare-earth carbonatites (Vuoriyarvi Massif, Russia). Geosciences 2018, 8, 281. [CrossRef]

31. Roedder, E. Fluid Inclusions. Reviews in Mineralogy; Ribbe, P.H., Ed.; Mineralogical Society of America: Blacksburg, VA, USA, 1984; Volume 12, ISBN 978-0-939950-16-4.

32. Kotel'nikova, Z.A.; Kotel'nikov, A.R. Method of synthetic fluid inclusions in quartz in experimental study of the water-sodium sulfate system. Geol. Ore Depos. 2009, 51, 68-73. [CrossRef]

33. Koster van Groos, A.F. High-pressure DTA study of the upper three-phase region in the system $\mathrm{Na}_{2} \mathrm{CO}_{3}-\mathrm{H}_{2} \mathrm{O}$. Am. Mineral. 1990, 75, 667-675.

34. Borisenko, A.S. Cryometric technique applied to studies of the saline composition of solution in gaseous fluid inclusions in minerals. Geol. i Geofiz. AN SSSR SO 1977, 8, 16-27. (In Russian)

35. Williams-Jones, A.E.; Migdisov, A.A.; Samson, I.M. Hydrothermal mobilisation of the rare earth elements-a tale of 'ceria' and 'yttria'. Elements 2012, 8, 355-360. [CrossRef]

36. Tropper, P.; Manning, C.E.; Harlov, D.E. Solubility of $\mathrm{CePO}_{4}$ monazite and $\mathrm{YPO}_{4}$ xenotime in $\mathrm{H}_{2} \mathrm{O}$ and $\mathrm{H}_{2} \mathrm{O}-\mathrm{NaCl}$ at $800^{\circ} \mathrm{C}$ and 1GPa: Implications for REE and $\mathrm{Y}$ transport during high-grade metamorphism. Chem. Geol. 2011, 282, 58-66. [CrossRef]

37. Tropper, P.; Manning, C.E.; Harlov, D.E. Experimental determination of $\mathrm{CePO}_{4}$ and $\mathrm{YPO}_{4}$ solubilities in $\mathrm{H}_{2} \mathrm{O}-\mathrm{NaF}$ at $800^{\circ} \mathrm{C}$ and $1 \mathrm{GPa}$ : Implications for rare earth element transport in high-grade metamorphic fluids. Geofluids 2013, 13, 372-380. [CrossRef]

38. Doroshkevich, A.G.; Ripp, G.S.; Moore, K.R. Genesis of the Khaluta alkaline-basic Ba-Sr carbonatite complex (West Transbaikala, Russia). Mineral. Petrol. 2010, 98, 245-268. [CrossRef]

39. Duraiswami, R.; Shaikh, T. Fluid-rock interaction in the Kangankunde Carbonatite Complex, Malawi: SEM based evidence for late stage pervasive hydrothermal mineralisation. Open Geosci. 2014, 6, 476-491. [CrossRef]

40. Cooper, A.F.; Collins, A.K.; Palin, J.M.; Spratt, J. Mineralogical evolution and REE mobility during crystallisation of ancylite-bearing ferrocarbonatite, Haast River, New Zealand. Lithos 2015, 216-217, 324-337. [CrossRef]

41. Nadeau, O.; Cayer, A.; Pelletier, M.; Stevenson, R.; Jébrak, M. The Paleoproterozoic Montviel carbonatite-hosted REE-Nb deposit, Abitibi, Canada: Geology, mineralogy, geochemistry and genesis. Ore Geol. Rev. 2015, 67, 314-335. [CrossRef]

42. Andersen, A.K.; Clark, J.G.; Larson, P.B.; Neill, O.K. Mineral chemistry and petrogenesis of a HFSE(+HREE) occurrence, peripheral to carbonatites of the Bear Lodge alkaline complex, Wyoming. Am. Mineral. 2016, 101, 1604-1623. [CrossRef]

43. Broom-Fendley, S.; Styles, M.T.; Appleton, J.D.; Gunn, G.; Wall, F. Evidence for dissolution-reprecipitation of apatite and preferential LREE mobility in carbonatite-derived late-stage hydrothermal processes. Am. Mineral. 2016, 101, 596-611. [CrossRef]

44. Prokopyev, I.R.; Borisenko, A.S.; Borovikov, A.A.; Pavlova, G.G. Origin of REE-rich ferrocarbonatites in southern Siberia (Russia): Implications based on melt and fluid inclusions. Mineral. Petrol. 2016, 110, 845-859. [CrossRef] 
45. Prokopyev, I.R.; Doroshkevich, A.G.; Sergeev, S.A.; Ernst, R.E.; Ponomarev, J.D.; Redina, A.A.; Chebotarev, D.A.; Nikolenko, A.M.; Dultsev, V.F.; Moroz, T.N.; et al. Petrography, mineralogy and SIMS U-Pb geochronology of 1.9-1.8 Ga carbonatites and associated alkaline rocks of the Central-Aldan magnesiocarbonatite province (South Yakutia, Russia). Mineral. Petrol. 2019, 113, 329-352. [CrossRef]

46. Andersen, A.K.; Larson, P.B.; Cosca, M.A. C-O stable isotope geochemistry and 40Ar/39Ar geochronology of the Bear Lodge carbonatite stockwork, Wyoming, USA. Lithos 2019, 324-325, 640-660. [CrossRef]

47. Dalsin, M.L.; Groat, L.A.; Creighton, S.; Evans, R.J. The mineralogy and geochemistry of the Wicheeda Carbonatite Complex, British Columbia, Canada. Ore Geol. Rev. 2015, 64, 523-542. [CrossRef]

48. Trofanenko, J.; Williams-Jones, A.E.; Simandl, G.J.; Migdisov, A.A. The nature and origin of the REE mineralization in the Wicheeda Carbonatite, British Columbia, Canada. Econ. Geol. 2016, 111, 199-223. [CrossRef]

49. Zaitsev, A.N.; Wall, F.; Le Bas, M.J. REE-Sr-Ba minerals from the Khibina carbonatites, Kola Peninsula, Russia: Their mineralogy, paragenesis and evolution. Mineral. Mag. 1998, 62, 225-250. [CrossRef]

50. Ngwenya, B.T. Hydrothermal rare earth mineralisation in carbonatites of the Tundulu complex, Malawi: Processes at the fluid/rock interface. Geochim. Cosmochim. Acta 1994, 58, 2061-2072. [CrossRef]

51. Ruberti, E.; Enrich, G.E.R.; Gomes, C.B.; Comin-Chiaramonti, P. Hydrothermal REE fluorocarbonate mineralization at Barra do Itapirapuã, a multiple stockwork carbonatite, southern Brazil. Can. Mineral. 2008, 46, 901-914. [CrossRef]

52. Rankin, A.H. Carbonatite-associated rare metal deposits: Composition and evolution of ore-forming fluids-The fluid inclusion evidence. In Rare-Element Geochemistry and Mineral Deposits. GAC Short Course Notes 17; Linnen, R.L., Samson, I.M., Eds.; Geological Association of Canada: St. John's, NL, Canada, 2005; pp. 299-314, ISBN 978-1-897095-08-9.

53. Borisenko, A.S.; Borovikov, A.A.; Vasyukova, E.A.; Pavlova, G.G.; Ragozin, A.L.; Prokop'ev, I.R.; Vladykin, N.V. Oxidized magmatogene fluids: Metal-bearing capacity and role in ore formation. Russ. Geol. Geophys. 2011, 52, 144-164. [CrossRef]

(C) 2020 by the authors. Licensee MDPI, Basel, Switzerland. This article is an open access article distributed under the terms and conditions of the Creative Commons Attribution (CC BY) license (http://creativecommons.org/licenses/by/4.0/). 